\title{
Neuregulin Receptor
}

National Cancer Institute

\section{Source}

National Cancer Institute. Neuregulin Receptor. NCI Thesaurus. Code C20061.

Comprised of the erbB2, erbB3, and erbB4 proteins. These proteins form homo and heterodimers, which complicates the assignment of specificities: it is known that erbB2 homodimer do not bind heregulin, but erbB2/erbB3 heterodimers do. 